\title{
Decidual $\mathrm{T}$ lymphocyte activation in hydatidiform mole
}

\author{
Sutatip Wongweragiat, Roger F Searle, Judith N Bulmer
}

\begin{abstract}
Aim-To quantify and compare decidual leucocyte subpopulations in complete and partial hydatidiform molar pregnancy with those in normal early pregnancy.

Methods-Decidual leucocytes were characterised using an avidin-biotin technique and a panel of monoclonal antibodies in formalin fixed, paraffin embedded decidual tissues from 10 normal first trimester pregnancy terminations and from 13 partial and 13 complete hydatidiform moles. Immunostained cells were fully quantitated and differences between subject groups were analysed using the Mann-Whitney test. T lymphocyte populations were further characterised using double immunohistochemical labelling. Results-The numbers and percentages of $\mathrm{CD}^{+}$and $\mathrm{CD}^{+} \mathrm{T}$ cells were significantly increased in complete hydatidiform moles compared with partial moles and normal early pregnancy decidua. No differences were found in the number or percentage of $\mathrm{CD8}^{+} \mathrm{T}$ cells. The $\mathrm{CD8}^{+}$to $\mathrm{CD}^{+} \mathrm{T}$ cell ratio decreased significantly in complete mole compared with partial mole and normal decidua. The numbers and percentages of $\mathrm{CD}^{2} 5 \mathrm{RO}^{+}$cells increased significantly in both partial and complete hydatidiform mole compared with normal first trimester decidua. Double labelling confirmed that $50 \%$ of $\mathrm{CD3}^{+} \mathrm{T}$ cells in complete and partial molar pregnancy coexpressed CD45RO, compared with $30 \%$ in normal pregnancy. Other leucocyte populations (eGLs, macrophages, $B$ cells, and classical natural killer cells) did not differ between complete and partial mole and normal pregnancy decidua.
\end{abstract}

Department of

Immunology,

University of

Newcastle upon Tyne,

Framlington Place,

Newcastle upon Tyne

NE2 4HH, UK

$S$ Wongweragiat

R F Searle

Department of Pathology, University of Newcastle upon

Tyne

J N Bulmer

Correspondence to: Dr Wongweragiat

email:

sutatip.wongweragiat@ ncl.ac.uk

Accepted for publication 12 July 1999

In normal pregnancy around $30 \%$ of stromal cells in decidualised endometrium are leucocytes. ${ }^{1}$ Of these, up to $70 \%$ are phenotypically unusual endometrial granulated lymphocytes (eGL) ${ }^{1}$; eGLs display natural killer (NK) cell cytotoxicity ${ }^{2-4}$ and produce various cytokines, ${ }^{5-9}$ but their in vivo function remains uncertain. $\mathrm{T}$ lymphocytes comprise approximately $10-20 \%$ of decidual leucocytes with a
$\mathrm{CD}^{+}$to $\mathrm{CD}^{+}$ratio of around $3: 1^{110}$; these cells are also a potential source of cytokines in uteroplacental tissues. It has been proposed that a local $\mathrm{T}$ helper (Th) 2-type cytokine response favours fetal survival and successful pregnancy, whereas a Th1-type cytokine response may be detrimental. ${ }^{11}$ Macrophages constitute approximately $20 \%$ of first trimester decidual leucocytes and may play a role in intrauterine immunoregulation and cytokine production. ${ }^{12-14}$ It has been suggested that cytokines produced locally by different leucocyte populations at the uteroplacental interface regulate normal trophoblast proliferation and invasion, although the precise mechanisms are unknown. ${ }^{11}{ }^{15-18}$

Hydatidiform mole is a gestational trophoblastic disease characterised by abnormal trophoblast proliferation. The incidence of molar pregnancy varies widely from $1 / 85$ pregnancies in Indonesia ${ }^{19}$ to $0.6-1 / 1000$ pregnancies in North America and Europe. ${ }^{20}$ Complete hydatidiform moles are usually diploid, with a 46 , XX karyotype, and are of androgenetic origin, the majority resulting from the fertilisation of an anuclear ovum by a haploid sperm which then duplicates its own chromosome. ${ }^{21}{ }^{22}$ In contrast, partial hydatidiform moles are generally triploid, resulting from the fertilisation of a normal ovum by two spermatozoa. ${ }^{23}$ Both partial and, more commonly, complete hydatidiform moles are associated with persistent trophoblastic disease. Since all the chromosomes are paternal in origin, a complete hydatidiform mole is an intrauterine allograft within the mother and may therefore be expected to stimulate maternal immune responses leading to fetal rejection. To date, there have been few and limited studies of maternal uterine immune responses in molar pregnancy. ${ }^{24-26}$ The present study was designed to characterise, quantify, and compare decidual leucocyte subpopulations and particularly $\mathrm{T}$ lymphocytes in complete and partial molar pregnancy with those in normal pregnancy to serve as a basis for the analysis of cytokine profiles in molar pregnancy. As well as analysing $\mathrm{T}$ lymphocyte subsets, expression of the CD45 isoforms CD45RA and CD45RO were analysed. CD45RA is expressed by naive or virgin $\mathrm{T}$ cells, whereas activated and memory $\mathrm{T}$ cells express CD $45 \mathrm{RO}^{27}$

\section{Methods}

TISSUES

Formalin fixed, paraffin embedded decidual tissues from 10 normal first trimester pregnancy terminations and from 12 partial and eight complete hydatidiform moles were re- 
Table 1 Primary monoclonal antibodies used on paraffin embedded sections

\begin{tabular}{lllll}
\hline Monoclonal antibody & Source & Specificity & Dilution & Pretreatment \\
\hline CD3 (NCL-CD3-PS1) & Novocastrat & T cells & $1: 100$ & Pressure cooker (citrate buffer, pH 6.0) \\
CD4 (NCL-CD4-1F6) & Novocastra & Helper T cells, macrophages & $1: 50$ & Pressure cooker (EDTA buffer, pH 8.0) \\
CD8 (NCL-CD8-295) & Novocastra & Cytotoxic/suppressor T cells, NK cells, thymocytes & $1: 2000$ & Pressure cooker (EDTA buffer, pH 8.0) \\
CD20 (L26) & Dako & B cells & $1: 400$ & Pressure cooker (citrate buffer, pH 6.0) \\
CD45 (NCL-LCA-RP) & Novocastra & Lymphocytes, monocytes, eosinophils & $1: 100$ & Trypsin 5 min \\
CD45 RA (NCL-MB1) & Novocastra & B cells, monocytes and a small proportion of T cells & $1: 60$ & No pretreatment \\
CD45 RO (NCL-UCHL1) & Novocastra & Reactive T cells, monocytes, macrophages & $1: 400$ & Pressure cooker (citrate buffer, pH 6.0) \\
CD56 (NCL-CD56-1B6) & Novocastra & NK cells, a subset of activated T cells & $1: 500$ & Pressure cooker (citrate buffer, pH 6.0) \\
CD57 (NCL-NK1) & Novocastra & NK cells & $1: 10$ & Trypsin 10 min \\
CD68 (NCL-CD68) & Novocastra & Macrophages & $1: 50$ & Trypsin 10 min \\
CD79a (CD79; JCB 117) & Dako & B cells & $1: 50$ & Pressure cooker (citrate buffer, pH 6.0) \\
Cytokeratin (8/18) (NCL-5D3) & Novocastra & Simple and glandular epithelium & $1: 20$ & Trypsin 10 min \\
CD34 (QBEND/10, NCL-END) & Novocastra & Haematopoietic progenitor cells, vascular endothelium & $1: 25$ & Trypsin 10 min \\
\hline
\end{tabular}

†Novocastra Laboratories, Newcastle upon Tyne, UK.

‡Dako, High Wycombe, UK.

trieved from archive files of the department of pathology, Royal Victoria Infirmary, Newcastle upon Tyne. One partial and five complete hydatidiform moles were retrieved from archive files of the department of obstetrics and gynaecology, Siriraj Hospital, Mahidol University, Bangkok. All tissue blocks were sectioned at $3 \mu \mathrm{m}$ and mounted on 3-aminopropyltriethoxysilane (APES; Sigma) coated slides. At least one section of each tissue was stained with haematoxylin and eosin (H\&E) to allow morphological assessment. Cases which showed histological evidence of decidual necrosis or inflammation identified by the presence of neutrophil polymorphs or plasma cells were not included in the study.

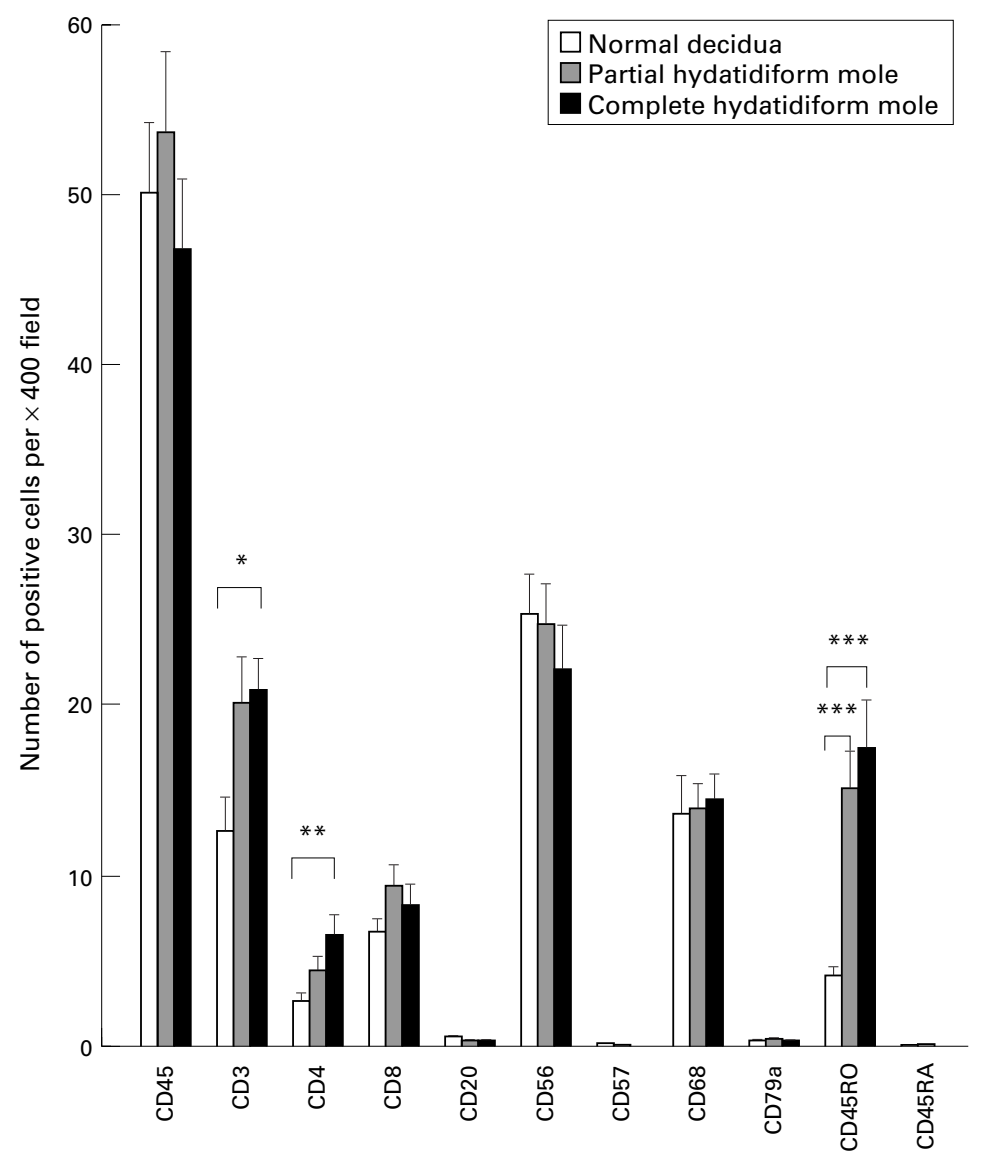

Figure 1 Decidual leucocyte populations in normal first trimester pregnancy and in partial and complete hydatidiform moles. Each bar represents the number of positive cells per $\times 400$ field. Error bars $=S E M .{ }^{\star} p<0.05 ;{ }^{\star \star} p<0.01 ;{ }^{\star \star \star} p<0.001$.
ANTIBODIES

A panel of 11 murine monoclonal antibodies was employed to characterise leucocyte subsets. Antibodies directed against CD34 (QBend10) and cytokeratin 8/18 (5D3) were used to identify endothelial and trophoblast cells, respectively. All antibody specificities, dilutions, and pretreatments are detailed in table 1.

\section{IMMUNOHISTOCHEMISTRY}

\section{Single labelling}

Sections were labelled using a streptavidinbiotin complex immunohistochemical technique with no pretreatment, trypsin pretreatment, or pressure cooking in citrate buffer, $\mathrm{pH}$ 6.0, or EDTA buffer, $\mathrm{pH}$ 8.0. For each antibody the optimal dilution, incubation time, and pretreatment were established using similarly fixed and processed positive control tonsil and neuroblastoma tissues, as appropriate.

Sections were deparaffinised and rehydrated before quenching of endogenous peroxidase activity by incubation for 10 minutes with $1.6 \%$ hydrogen peroxide in methanol. For trypsinisation sections were incubated with $2.5 \%$ trypsin (Difco Laboratories) in distilled water, $\mathrm{pH} 7.8$, containing $2.5 \%$ calcium chloride for five or 10 minutes. For pressure cooking sections were heated for one minute in citrate buffer, $\mathrm{pH}$ 6.0, or EDTA buffer, $\mathrm{pH}$ 8.0, as appropriate. For anti-CD4, CD8, and CD45RO, pretreatment by pressure cooking was followed by the use of an avidin/biotin blocking kit (Vector Laboratories) to block endogenous avidin and biotin activity. All sections were then overlain with $10 \%$ normal rabbit serum (NRS) in $0.1 \mathrm{M}$ Tris/0.05 $\mathrm{M}$ saline (TBS), $\mathrm{pH} 7.6$, for 10 minutes and then incubated with the primary antibody appropriately diluted in NRS for 60 minutes or overnight (anti-CD45). After washing twice in TBS, sections were incubated with biotinylated rabbit antimouse immunoglobulins (Dako), diluted 1:500 in NRS, for 30 minutes followed by streptavidin-biotin peroxidase complex (1:100 in NRS, Dako) for 30 minutes. The reaction was developed with 3,3'-diaminobenzidine (DAB; Sigma) containing $0.02 \%$ hydrogen peroxide for five minutes. Sections were lightly counterstained with Mayer's haematoxylin, dehydrated, cleared in xylene, and mounted in DPX synthetic resin (Raymond A Lamb Co). Tonsil sections were used as a posi- 


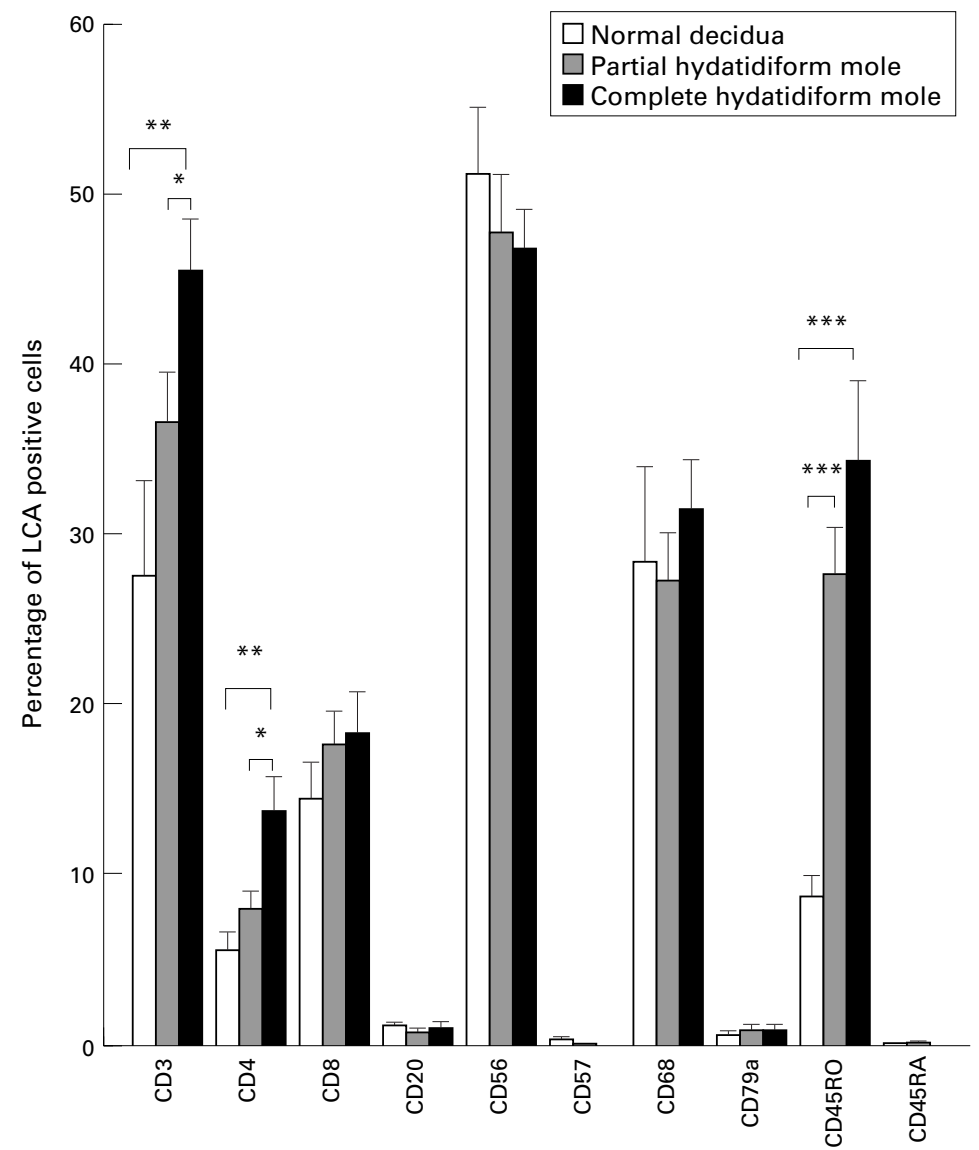

Figure 2 Decidual leucocyte populations in normal first trimester pregnancy and in partial and complete hydatidiform moles. Each bar represents the percentage of the $C D 45^{+}$ $\left(L C A^{+}\right)$population. Error bars $=$SEM. ${ }^{\star} p<0.05 ;{ }^{\star \star} p<0.01 ;{ }^{\star \star \star} p<0.001$.

tive control for all antibodies except CD56 for which neuroblastoma sections were the positive control. Replacement of the primary antibody by normal serum was performed as a negative control for all specimens.

\section{Double labelling}

To assess expression of CD45RO by $\mathrm{CD}^{+}$and $\mathrm{CD}_{5} 6^{+}$cells, a sequential double immunohistochemical labelling technique was applied to selected normal and molar pregnancy samples. After the appropriate pretreatment, the sections were incubated with normal horse blocking serum (NHS) for 10 minutes and then sequentially with either anti-CD3 or antiCD56 for 60 minutes, biotinylated horse antimouse immunoglobulins for 30 minutes, and

Table 2 Decidual leucocyte counts in normal first trimester pregnancy and in partial and complete hydatidiform moles

\begin{tabular}{llll}
\hline $\begin{array}{l}\text { Decidual leucocyte } \\
\text { populations }\end{array}$ & Normal pregnancy & $\begin{array}{l}\text { Partial hydatidiform } \\
\text { mole }\end{array}$ & $\begin{array}{l}\text { Complete hydatidiform } \\
\text { mole }\end{array}$ \\
\hline CD45 (LCA) & $47(37.5$ to 73.3$)$ & $53.5(29.6$ to 80.4$)$ & $42.7(27.4$ to 86.0$)$ \\
CD3 & $11.9(5.8$ to 27.2$)$ & $20.0(9.0$ to 35.7$)$ & $20.0(8.7$ to 31.0$)$ \\
CD4 & $2.4(1.2$ to 5.3$)$ & $2.8(1.2$ to 12.0$)$ & $4.2(1.8$ to 18.3$)$ \\
CD8 & $7.5(2.7$ to 9.8$)$ & $8.5(2.3$ to 18.0$)$ & $7.6(2.8$ to 16.4$)$ \\
CD20 & $0.5(0.0$ to 1.5$)$ & $0.2(0.0$ to 1.8$)$ & $0.0(0.0$ to 1.7$)$ \\
CD56 & $27.2(12.0$ to 37.3$)$ & $23.8(14.1$ to 41.7$)$ & $19.7(11.4$ to 46.0$)$ \\
CD57 & $0.0(0.0$ to 0.8$)$ & $0.0(0.0$ to 0.3$)$ & $0.0(0.0$ to 0.0$)$ \\
CD68 & $12.6(6.7$ to 28.0$)$ & $13.5(7.0$ to 25.8$)$ & $16.5(8.7$ to 21.0$)$ \\
CD79a & $0.0(0.0$ to 1.0$)$ & $0.2(0.0$ to 2.0$)$ & $0.2(0.0$ to 1.7$)$ \\
CD45RA & $0.0(0.0$ to 0.3$)$ & $0(0.0$ to 0.7$)$ & $0.0(0.0$ to 0.0$)$ \\
CD45RO & $3.9(2.5$ to 8.5$)$ & $13.3(5.8$ to 30.0$)$ & $13.3(4.0$ to 39.0$)$ \\
\hline
\end{tabular}

The median and range of the number of positive cells per $\times 400$ field of each leucocyte population are shown. avidin-biotin peroxidase complex for $30 \mathrm{~min}$ utes (Vectastain Elite; Vector Laboratories). This reaction was developed with DAB as described above to produce a brown reaction product. After thorough washing in running water and a 10 minute incubation in NHS, the sections were incubated with anti-CD45RO for 60 minutes, with biotinylated antimouse immunoglobulins for 30 minutes, and finally with $\mathrm{ABC}$ alkaline phosphatase for 30 minutes (Vectastain alkaline phosphatase kit; Vector Laboratories). The reaction was developed with alkaline phosphatase substrate kit III (Vecta Blue; Vector Laboratories) at room temperature until the appropriate blue colour developed, usually after approximately $10 \mathrm{~min}$ utes. Double labelled sections were not counterstained and were mounted with $\mathrm{BDH}$ aquamount (BDH Co). Positive controls were performed for anti-CD3, anti-CD56, and antiCD 45RO antibodies and for CD45RO/CD3 and $\mathrm{CD} 45 \mathrm{RO} / \mathrm{CD} 56$ double labelling using normal tonsil. Single labelling for CD3, CD56, and CD45RO was performed on adjacent sections for each sample in order to rule out spurious double labelling. Negative controls were performed at each level of the double labelling procedure.

\section{QUANTIFICATION}

Positive cells, identified by the presence of brown membrane reactivity, were quantified at $\times 400$ magnification using a $10 \times 10 \mathrm{~mm}$ graticule. At least $200 \mathrm{CD} 45$ positive $\left(\mathrm{LCA}^{+}\right)$ decidual stromal cells were counted in comparable areas of consecutive sections and the results were expressed as a percentage of $\mathrm{LCA}^{+}$ cells or as the number of positive cells per $\times 400$ field. For the anti-CD4 and anti-CD45RO antibodies which also stained macrophages, only small rounded lymphocytic cells were counted. Similarly, anti-CD3 also stained some eGLs and again care was taken to count only small rounded $\mathrm{CD}^{+}$lymphocytes with little cytoplasm. Double labelled sections were assessed by counting the number of single (brown or blue) and double (brown and blue) labelled positive cells in each field. Statistical analysis was performed using the MannWhitney test with the conventional $\mathrm{p}<0.05$ significance level.

\section{Results}

QUANTITATION OF DECIDUAL LEUCOCYTES

Normal pregnancy

The numbers and proportions of decidual leucocytes in normal first trimester pregnancy confirmed previous reports ${ }^{12}$ and are summarised in figs 1 and 2 and tables 2 and 3. In normal early pregnancy decidua, most $\mathrm{LCA}^{+}$cells were $\mathrm{CD}^{2} 6^{+}$eGLs (mean (SEM), 51.2 (3.9)\%), CD $68^{+}$macrophages (28.5 (5.5)\%), and $\mathrm{CD}^{+} \mathrm{T}$ cells $(27.6(5.6) \%)$.

\section{Hydatidiform mole}

In complete hydatidiform moles (CHM), both the number and percentage of $\mathrm{CD}^{+} \mathrm{T}$ cells were significantly increased compared with normal early pregnancy decidua (NP): number, NP 12.7 (2.0), CHM 20.9 (1.8), 
Table 3 Decidual leucocyte counts in normal first trimester pregnancy and in partial and complete hydatidiform moles

\begin{tabular}{llll}
\hline $\begin{array}{l}\text { Decidual leucocyte } \\
\text { populations }\end{array}$ & Normal pregnancy & $\begin{array}{l}\text { Partial hydatidiform } \\
\text { mole }\end{array}$ & $\begin{array}{l}\text { Complete hydatidiform } \\
\text { mole }\end{array}$ \\
\hline CD3 & $25.2(8.9$ to 72.1$)$ & $39.1(21.2$ to 50.0$)$ & $48.3(23.4$ to 59.1$)$ \\
CD4 & $3.9(2.5$ to 12.4$)$ & $6.8(3.5$ to 15.0$)$ & $12.3(3.9$ to 29.2$)$ \\
CD8 & $16.3(4.0$ to 23.5$)$ & $15.8(4.2$ to 32.4$)$ & $15.6(6.6$ to 32.3$)$ \\
CD20 & $1.0(0.0$ to 2.5$)$ & $0.5(0.0$ to 4.5$)$ & $0.0(0.0$ to 5.5$)$ \\
CD56 & $50.2(31.7$ to 79.2$)$ & $52.5(21.9$ to 60.7$)$ & $43.0(36.4$ to 64.3$)$ \\
CD57 & $0.0(0.0$ to 2.2$)$ & $0.0(0.0$ to 0.6$)$ & $0.0(0.0$ to 0.0$)$ \\
CD68 & $24.9(9.9$ to 74.3$)$ & $25.1(11.4$ to 47.2$)$ & $31.8(3.3$ to 46.4$)$ \\
CD79a & $0.0(0.0$ to 1.9$)$ & $0.4(0.0$ to 4.5$)$ & $0.4(0.0$ to 5.0$)$ \\
CD45RA & $0.0(0.0$ to 0.5$)$ & $0.0(0.0$ to 1.4$)$ & $0.0(0.0$ to 0.0$)$ \\
CD45RO & $7.6(4.0$ to 15.7$)$ & $24.8(12.0$ to 40.3$)$ & $38.6(8.2$ to 67.1$)$ \\
\hline
\end{tabular}

The median and range of the percentage of LCA positive cells of each leucocyte population are shown. percentages of $\mathrm{CD}^{+}, \mathrm{CD}^{+}$, and $\mathrm{CD} 8^{+} \mathrm{T}$ cells also increased in partial hydatidiform moles compared with normal early pregnancy decidua, the differences were not significant. The ratio of $\mathrm{CD}^{+}$to $\mathrm{CD} 4^{+} \mathrm{T}$ cells was significantly decreased in complete hydatidiform mole (1.6:1) compared with normal early pregnancy decidua (3.2:1, p = 0.02) and partial mole $(2.4: 1, \mathrm{p}=0.0378)$.

The numbers and percentages of CD45RO ${ }^{+}$ cells were significantly increased in both partial (number, 15.1 (2.2), $\mathrm{p}=0.0001$; percentage, $27.7(2.7) \%, \quad \mathrm{p}=0.0002)$ and complete (number, 17.4 (2.9), $\mathrm{p}=0.0004$; percentage, $34.3(4.7) \%, p=0.0002)$ hydatidiform mole compared with normal first trimester decidua (number 4.2 (0.6), percentage 8.8 (1.3)\%) (figs 1, 2, and 6; tables 2 and 3). As in normal

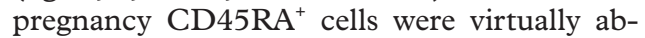
sent from partial and complete molar pregnancy decidua.

The number and percentage of $\mathrm{CD} 56^{+}$cells (eGLs) in decidua from complete hydatidiform moles did not differ significantly from those in partial moles and normal first trimester decidua. Although $\mathrm{CD} 68^{+}$macrophages increased in complete hydatidiform moles compared with normal early pregnancy decidua and partial hydatidiform mole, this difference was not significant. As in normal decidua, $\mathrm{CD} 79 \mathrm{a}^{+}$and $\mathrm{CD} 20^{+} \mathrm{B}$ cells and $\mathrm{CD} 57^{+}$natural killer cells were rare in molar pregnancy decidua (figs 1 and 2; tables 2 and 3 ).

DOUBLE IMMUNOHISTOCHEMICAL LABELLING Double immunohistochemical labelling confirmed the increase in the numbers of $\mathrm{CD}^{+}$ cells in complete hydatidiform moles compared with normal decidua. The numbers normal pregnancy decidua (figs 1,2 , and 5 ; tables 2 and 3). Although the numbers and

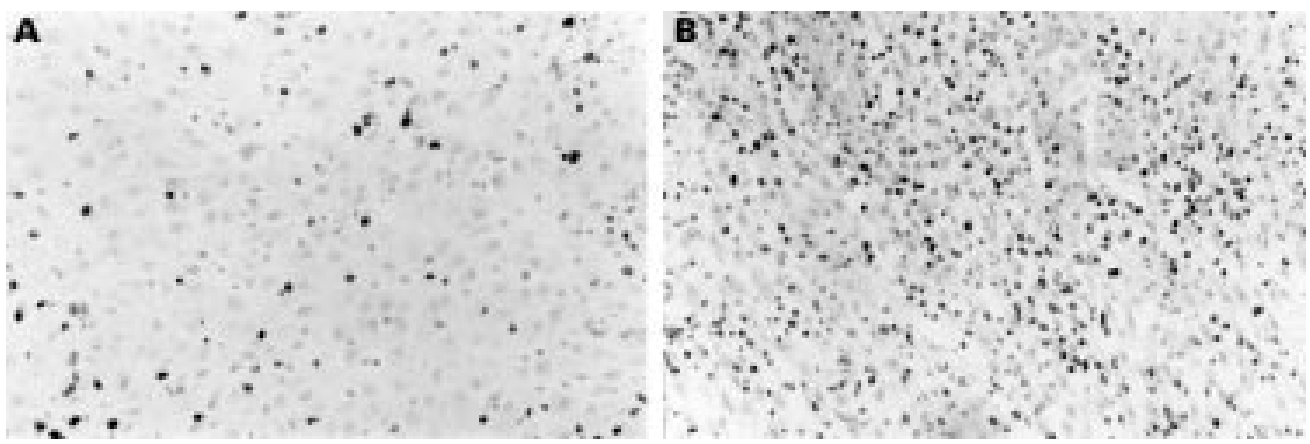

Figure 3 Formalin fixed, paraffin embedded sections of decidua from (A) normal first trimester pregnancy; (B) complete hydatidiform mole immunostained for CD3. Note the increased number of $T$ cells in complete hydatidiform mole.

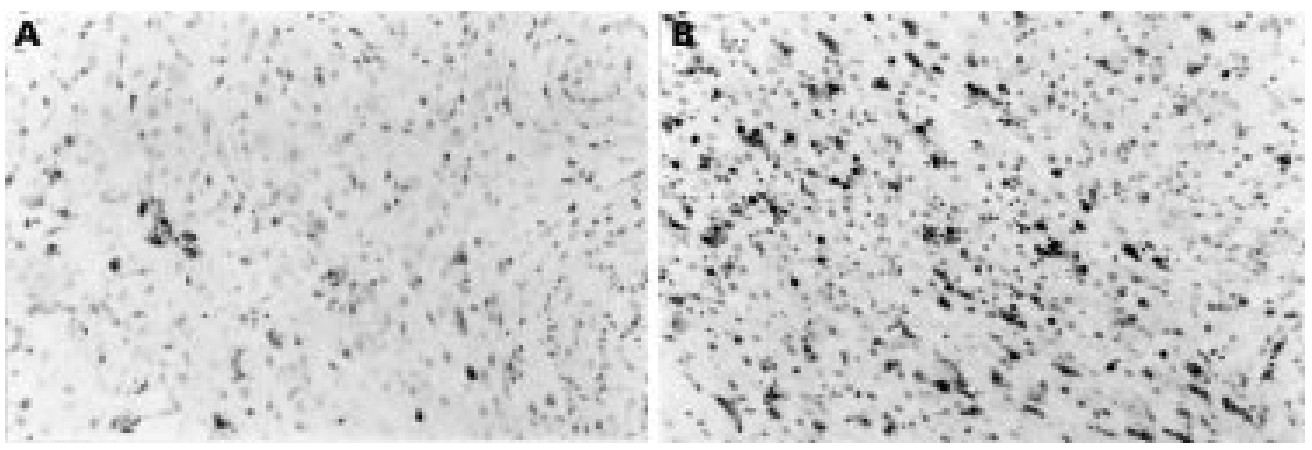

Figure 4 Decidua from (A) normal first trimester pregnancy; (B) complete hydatidiform mole immunostained for CD4 showing increased numbers of $\mathrm{CD}^{+}$cells in complete hydatidiform mole. 


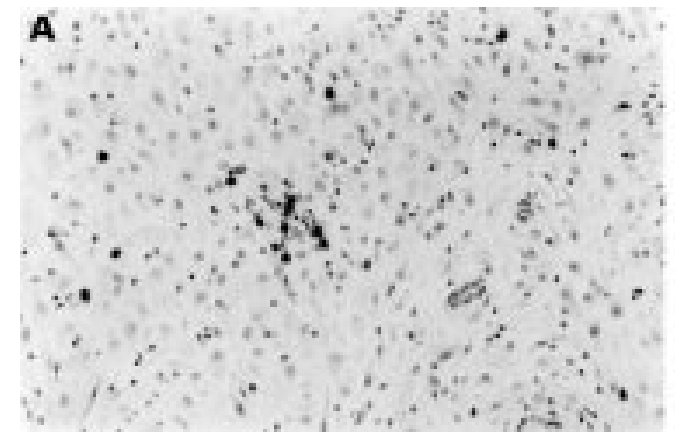

Figure 5 Decidua from (A) normal first trimester pregnancy; (B) complete hydatidiform mole immunostained for CD8. Numbers of positive cells are comparable.
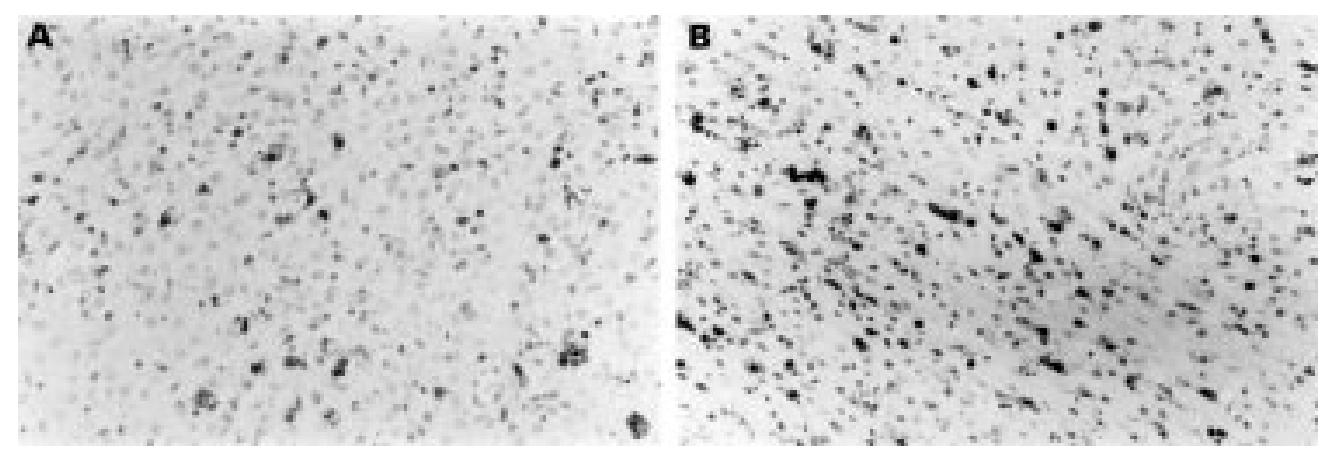

Figure 6 Decidua from (A) normal first trimester pregnancy; (B) complete hydatidiform mole immunostained for $\mathrm{CD} 45 \mathrm{RO}$. Increased numbers of $\mathrm{CD} 45 \mathrm{RO}^{+}$cells are seen in complete hydatidiform mole.

of $\mathrm{CD}^{+}$cells that coexpressed CD45RO increased in both partial and complete hydatidiform moles (table 4 ); up to $50 \%$ of $\mathrm{CD}^{+}$ cells in molar pregnancy decidua coexpressed CD45RO, compared with $30 \%$ in normal early pregnancy decidua. In contrast, the number of decidual $\mathrm{CD}^{2} 6^{+}$cells that coexpressed CD45RO was comparable in normal pregnancy and in partial and complete hydatidiform moles (data not shown).

\section{Discussion}

Our analysis of decidual leucocytes in normal first trimester pregnancy is in agreement with previous studies of frozen tissues. ${ }^{1} \mathrm{~T}$ cells accounted for a lower proportion of the stromal leucocytes compared with the $\mathrm{CD} 56^{+}$granulated lymphocytes but, as reported previously, many decidual $\mathrm{T}$ cells were $\mathrm{CD} 45 \mathrm{RO}^{+}$memory cells. ${ }^{28}$ Decidual $\mathrm{T}$ cells have also been reported to express various activation markers including HLA-DR, CD69, and interleukin (IL)-2 receptor $\alpha$ and $\beta$, although expression of the $\alpha$ IL-2 receptor subunit has been disputed. ${ }^{29-33}$ Despite this evidence of activation, to date there have been no functional studies of decidual $\mathrm{T}$ cells in normal pregnancy. It has been proposed that Th2-type cytokines are necessary for successful preg-

Table 4 Number of decidual $\mathrm{CD}^{+}$cells that express CD45RO in normal early pregnancy decidua and in partial and complete hydatidiform moles

\begin{tabular}{llll}
\hline Samples & $\begin{array}{l}\text { Single labelled } C D 3^{+} \\
\text {cells/field }\end{array}$ & $\begin{array}{l}\text { Double labelled } \\
C D 3^{+} C D 45 R O^{+} \\
\text {cells/field }\end{array}$ & $\begin{array}{l}\text { Total number of } \\
\text { CD } 3^{+} \text {cells/field }\end{array}$ \\
\hline Normal decidua & $5.80(0.80)$ & $2.33(0.33)$ & $8.17(1.17)$ \\
Partial hydatidiform mole & $10.13(0.63)$ & $8.25(0.50)$ & $18.13(8.8)$ \\
Complete hydatidiform mole & $11.09(1.92)$ & $10.42(1.25)$ & $21.50(3.17)$
\end{tabular}

Values are mean $(\mathrm{SEM})$ number of cells per $\times 400$ field (three to six fields were counted for each case). nancy, whereas Th1 type cytokines may be deleterious. ${ }^{11}$ Although it has been reported that a wide range of cytokines has been produced in human uteroplacental tissues, ${ }^{6710131434}$ the cytokine profile of decidual $\mathrm{T}$ cells has not been fully defined. However, recent studies of $\mathrm{T}$ cell clones from early pregnancy decidua have indicated defective production of Th2 type cytokines in unexplained recurrent miscarriage compared with normal first trimester pregnancy. ${ }^{35}$ It can be hypothesised that the abnormal trophoblast proliferation and invasion in gestational trophoblastic neoplasia may be associated with an abnormal decidual leucocyte profile and hence an altered local cytokine milieu.

As complete hydatidiform mole is androgenetic, it appears likely that molar trophoblast may stimulate an altered maternal immune response. Our study extends previous immunohistochemical studies of $T$ cell populations in complete molar pregnancy decidua. ${ }^{25}$ $\mathrm{CD}^{+} \mathrm{T}$ cells accounted for a larger percentage of the leucocytes, with a dramatic increase in the number and proportion of CD45RO ${ }^{+}$cells. Moreover, the $\mathrm{CD} 4^{+} \mathrm{T}$ cell population which accounts for only a small proportion of decidual $\mathrm{T}$ cells in normal first trimester decidua was increased significantly in complete molar pregnancy, with an altered CD8:CD4 ratio of 1.6:1 in complete moles compared with $3.2: 1$ in normal pregnancy. These findings conflict with a previous study which reported that, although $\mathrm{CD} 4^{+} \mathrm{T}$ cells increased in complete molar pregnancy decidua, $\mathrm{CD}^{+} \mathrm{T}$ cells formed only a minority decidual $\mathrm{T}$ cell population, comprising only one quarter to one third of the total number of $\mathrm{T}$ cells. ${ }^{25}$ This may reflect the use of different techniques: the latter 
study used frozen tissues and an indirect immunoperoxidase method, whereas the present study used a large number of paraffin embedded tissues with heat mediated antigen retrieval and a more sensitive avidin-biotin peroxidase technique. Moreover, $\mathrm{CD}^{+}$macrophages may have been included in the assessment of CD $4^{+} \mathrm{T}$ cells. ${ }^{25}$

Our findings of altered activated CD45RO ${ }^{+}$ $\mathrm{T}$ cells in molar pregnancy decidua suggest that an altered maternal immune response may be induced by molar trophoblast. The mechanisms of $\mathrm{T}$ cell activation in normal pregnancy decidua are unknown. Extravillous trophoblast in normal pregnancy expresses a non-classical class I MHC antigen, HLA-G, which shows limited polymorphism. ${ }^{36} \mathrm{MHC}$ antigen expression by molar trophoblast has been less extensively investigated but evidence indicates similar MHC antigen expression by molar trophoblast. ${ }^{37}$ Moreover, expression of HLA-G by choriocarcinoma cell lines has been well documented. ${ }^{38}$ It is possible therefore that the invasive trophoblast within decidua leads to activation of decidual $\mathrm{T}$ cells. Despite the similarities in MHC expression, the present results suggest that this response may differ for molar trophoblast.

The function of $\mathrm{T}$ cells in normal pregnancy decidua is unknown, although it is reasonable to suggest that they contribute to local cytokine production. It is not known whether the increased numbers of $\mathrm{CD}^{+}$and $\mathrm{CD} 45 \mathrm{RO}^{+} \mathrm{T}$ cells reflect altered cytokine production which could enhance either cell-mediated cytotoxicity or humoral immunity in response to molar trophoblast. It has been reported that cytotrophoblast cells in normal pregnancy and complete hydatidiform mole express Fas ligand (FasL) which may induce apoptosis of decidual activated CD95(Fas) ${ }^{+} \mathrm{T}$ cells. ${ }^{39}$ The presence of increased numbers of activated $\mathrm{T}$ cells in molar pregnancy decidua suggests that there may be an increased turnover rate of these activated $\mathrm{T}$ cells in response to the molar trophoblast. The absence of B cells, immunoglobulin, and complement deposition at the molar implantation $\operatorname{site}^{26}$ suggests that humoral immunity is not the primary immune response mechanism. It appears unlikely that the alterations in decidual leucocyte populations noted in the present study reflect decidual inflammation. B cells were not a feature of molar pregnancy decidua and, moreover, none of the samples showed evidence of decidual necrosis, acute inflammatory cells, or plasma cells.

Further studies are required to clarify the role of decidual leucocytes, particularly $\mathrm{T}$ cells, in molar pregnancy. We are currently performing an immunohistochemical study of decidual $\mathrm{T}$ cell cytokine expression in molar pregnancy with the aim of elucidating the in vivo role of these cells.

We wish to thank Dr Somchaya Neungton (department of obstetrics and gynaecology, Siriraj Hospital, Bangkok, Thailand) for his kind cooperation in retrieving and providing us land) for his kind cooperation in retrieving and providing us and Ms Barbara Innes for their technical assistance.
1 Bulmer JN, Morrison L, Longfellow M, et al. Granulated lymphocytes in human endometrium: histochemical and immunohistochemical studies. Hum Reprod 1991;6: $791-8$.

2 Ferry BL, Starkey PM, Sargent IL, et al. Cell populations in the human early pregnancy decidua: natural killer activity and response to interleukin-2 of CD56-positive large granular lymphocytes. Immunology 1990;70:446-52.

3 Ritson A, Bulmer JN. Isolation and functional studies of granulated lymphocytes in first trimester human decidua. Clin Exp Immunol 1989; 77:263-8.

4 King A, Birkby C, Loke YW. Early human decidual cells exhibit NK activity against the K562 cell line but not against first trimester trophoblast. Cell Immunol 1989;118: 337-44.

5 Jokhi PP, King A, Boocock C, et al. Secretion of colony stimulating factor-1 by human first trimester placental and decidual cell populations and the effect of this cytokine on trophoblast thymidine uptake in vitro. Hum Reprod 1995;10:2800-7.

6 Jokhi PP, King A, Loke YW. Production of granulocytemacrophage colony-stimulating factor by human trophoblast cells and by decidual large granular lymphocytes. Hum Reprod 1994;9:1660-9.

7 Jokhi PP, King A, Sharkey AM, et al. Screening for cytokine messenger ribonucleic acids in purified human decidual lymphocyte populations by the reverse-transcriptase polymerase chain reaction. F Immunol 1994;153:4427-35.

8 Clark DA, Vince G, Flanders KC, et al. CD $56+$ lymphoid cells in human first trimester pregnancy decidua as a source of novel transforming growth factor-beta 2-related immuof novel transforming growth factor-beta 2-related

9 Saito S, Nishikawa K, Morri T, et al. Cytokine production by CD16-CD56 $6^{\text {bright }}$ natural killer cells in the human early pregnancy decidua. Int Immunol 1993;5:559-63.

10 Loke YW, King A. Human implantation: cell biology and immunology. Cambridge: Cambridge University Press, 1995.

11 Wegmann TG, Lin H, Guilbert L, et al. Bidirectional cytokine interelations in the maternal-fetal relationship: is successful pregnancy a Th2 phenomenon? Immunol Today 1993;14:353-6.

12 Parhar RS, Yagel S, Lala PK. PGE2-mediated immunosuppression by first trimester human decidual cells blocks activation of maternal leukocytes in the decidua with potential anti-trophoblast activity. Cell Immunol 1989;120: potential

13 Shorter SC, Vince GS, Starkey PM. Production of granulocyte colony-stimulating factor at the materno-foetal interface in human pregnancy. Immunology 1992;75:46874

14 Vince SG, Shorter S, Starkey P, et al. Localization of tumour necrosis factor production in cells at the materno/fetal interface in human pregnancy. Clin Exp Immunol 1992;88: 174-80.

15 Yui J, Garcia-Lloret M, Wegmann TG, et al. Cytotoxicity of tumour necrosis factor-alpha and gamma-interferon against primary human placental trophoblasts. Placenta 1994;15:819-35.

16 Tranchot-Diallo J, Gras G, Parnet-Mathieu F, et al. Modulations of cytokine expression in pregnant women. $A m \mathcal{F}$ Reprod Immunol 1997;37:215-26.

17 Todt JC, Yang Y, Lei J, et al. Effects of tumour necrosis factor-alpha on human trophoblast cell adhesion and motility. Am f Reprod Immunol 1996;36:65-71.

8 de Moraes-Pinto MI, Vince GS, Flanagan BF, et al. Localization of IL-4 and IL-4 receptors in the human term placenta, decidua and amniochorionic membranes. Immunology 1997;90:87-94.

19 Buckley JD. The epidemiology of molar pregnancy and choriocarcinoma. Clin Obstet Gynecol 1984;27:153-9.

20 Palmer JR. Advances in the epidemiology of gestational trophoblastic disease. F Reprod Med 1994;39:155-62.

21 Kajii T, Ohama K. Androgenetic origin of hydatidiform (a)ii T, Ohama K. Androgeneti

22 Yamashita K, Wake N, Araki T, et al. Human lymphocyte antigen expression in hydatidiform mole: androgenesis folowing fertilization by a haploid sperm. Am f Obstet Gynecol 1979;135:597-600

23 Szulman AE, Surti U. The syndromes of hydatidiform mole. I. Cytogenetic and morphologic correlations. Am f Obstet Gynecol 1978;131:665-71.

24 Bulmer JN, Johnson PM, Sasagawa M, et al. Immunohistochemical studies of fetal trophoblast and maternal decidua in hydatidiform mole and choriocarcinoma. Placenta 1988; 9:183-200.

25 Kabawat SE, Mostoufi-Zadeh M, Berkowitz RS, et al. Implantation site in complete molar pregnancy: a study of Implantation site in complete molar pregnancy: a study of immunologically competent cells with mo

26 Berkowitz RS, Mostoufizadeh GM, Kabawat SE, et al. Immunopathologic study of the implantation site in molar pregnancy. Am f Obstet Gynecol 1982;144:925-30.

27 Janeway CA, Travers $\mathrm{P}$, Walport $\mathrm{M}$, et al. Immunobiology: the immune system in health and disease, 4th ed. Edinburgh: Churchill Livingstone, 1999.

28 Saito S, Nishikawa K, Morii T, et al. A study of CD45RO, CD45RA and CD29 antigen expression on human decidual $\mathrm{T}$ cells in an early stage of pregnancy. Immunol Lett 1994;40:193-7.

29 Tabibzadeh SS, Satyaswaroop PG. Sex steroid receptors in lymphoid cells of human endometrium. Am $\mathcal{F}$ Clin Pathol 1989;91:656-63. 
30 Chen CK, Huang SC, Chen CL, et al. Increased expressions of CD69 and HLA-DR but not of CD25 or CD71 on endometrial T lymphocytes of nonpregnant women. Hum Immunol 1995;42:227-32.

31 Saito S, Nishikawa K, Morii T, et al. Expression of activation antigens CD69, HLA-DR, interleukin-2 receptor-alpha (IL-2R alpha) and IL-2R beta on $\mathrm{T}$ cells of human decidua at an early stage of pregnancy. Immunology 1992;75:710-12.

32 Starkey PM. Expression on cells of early human pregnancy decidua, of the p75, IL-2 and p145, IL-4 receptor proteins. Immunology 1991;73:64-70.

33 Bulmer JN, Johnson PM. The T-lymphocyte population in first-trimester human decidua does not express the interleukin-2 receptor. Immunology 1986;58:685-7.

34 King A, Jokhi PP, Smith SK, et al. Screening for cytokine mRNA in human villous and extravillous trophoblasts using the reverse-transcriptase polymerase chain reaction (RT-PCR). Cytokine 1995;7:364-71.
35 Piccinni MP, Beloni L, Livi C, et al. Defective production of both leukemia inhibitory factor and type 2 T-helper cytokines by decidual $\mathrm{T}$ cells in unexplained recurrent abortions. Nature Med 1998;4:1020-4.

36 Alizadeh M, Legras C, Semana G, et al. Evidence for a polymorphism of HLA-G gene. Hum Immunol 1993;38:20612.

37 Sunderland CA, Redman CW, Stirrat GM. Characterisation of HLA antigens on hydatidiform mole. Am $\mathcal{f}$ Obstet Gynecol 1985;151:130-5.

38 Risk JM, Johnson PM. Northern blot analysis of HLA-G expression by BeWo human choriocarcinoma cells. $f$ Reprod Immunol 1990;18:199-203.

39 Mor G, Gutierrez LS, Eliza M, et al. Fas-Fas ligand systeminduced apoptosis in human placenta and gestational trophoblastic disease. Am F Reprod Immunol 1998;40:8994. 